\title{
DESDE MI VENTANA
}

Sólo veo ventanas cerradas desde mi ventana

Ventanas que dan a ventanas, que dan a ventanas

Las otras ventanas no dejan entrar la luz

Sólo la reflejan del horizonte que no vuela

¿Por qué nadie abre las ventanas,

corre las cortinas?

Tuve un amigo que me decía

¿y tú por qué no cierras las ventanas,

corres las cortinas?

He ahí el poderoso misterio.

Unos cierran ventanas

otros las abren.

\section{¿QUÉ MÁS?}

Porque debe haber más

Siempre hay más. 